Trivent Publishing

(C) The Authors, 2016

Available online at http://trivent-publishing.eu/

Series: Philosophy, Communication, Media Sciences

Volume: Communication Today: An Overview from Online Journalism to Applied Philosophy

\title{
The Possibility of Global Bioethics in a Globalized World
}

\author{
Maria Sinaci \\ Department of Social Sciences, "Vasile Goldiş" West University of Arad, Romania \\ maria.sinaci@uvvg.ro
}

\begin{abstract}
This paper examines the possibility of the existence of global bioethics in a world in full globalization process which faces complex problems and requires ethical solutions and approaches based on international collaboration. The first part of this paper explains the meaning of "global bioethics" and its particular meaning used in this paper -- in order to avoid any confusion. Further on, the latest stage of bioethics is analyzed: its transition from its local to its global dimension. The main thesis of this study is that global bioethical construction can generate closeness in the approaches related to bioethics, given that universal values and norms are identified provided that this is not an absolute (albeit impossible) moral consensus. This study argues the possibility of global bioethics from a transversal perspective, exploring the fields of human rights, cultural pluralism, and religion.
\end{abstract}

\section{Keywords:}

Globalization; bioethics; human rights; ethical value; religion. 


\section{Introduction}

Although bioethics has existed as a concept for thousands of years (in the legacy found in the writings, religions, and cultures of peoples around the world), it only materialized into a field of study relatively late, after the 1970s. V. R. Potter introduced the term "bioethics" in his work Bioethics: Bridges to the Future published in 1971, where he also highlighted the necessity of bioethics as "a new field to combine biological knowledge with that of human values." ${ }^{1}$ New scientific discoveries and their implementation without ethical perspectives may endanger humanity and even the survival of the species. This thesis led to the emergence of bioethics as a necessary discipline which had to encompass problems regarding the human being, as well as the biosphere, altogether. In fact, Potter expressed his lack of trust in humankind's capacity of survival, particularly because of scientific progress. The author's solution for wisely using these new discoveries for the survival of the human species is the following: creating a bridge between the technical and the human-social sciences, thus giving bioethics a large area to unfold, a fact which may lead to global bioethics.

In the following years, the definitions of bioethics were enriched with ethical and philosophical reflections regarding medical praxis in the context of new scientific discoveries (highlighting human life and human rights). Contemporary debates in bioethics are centred on subjects such as euthanasia, eugenics, experiments on human subjects, physician-assisted suicide, organ transplants; furthermore, these debates evaluate the ethical implications generated by the biotechnologies which deal with the human embryo (abortion, cloning, assisted reproductive technology, stem cell therapy) and genetic engineering. Today, bioethics is understood (in its most common sense) as focusing on the ethical and legal controversies which develop from medical services, as well as on research problems of biomedical nature.

The amazing social and technological changes which have occurred in the past decades solicited an ethical perspective, especially on a normative and meta-ethical level, which materialized in crosscultural approaches marked by the research for global laws, principles, and collective moral values. One may argue that there even existed a pressing need for approaching bioethics on a global level. By extension, the possibility of global bioethics was analyzed from various perspectives and on multiple levels. Often times however, the understanding of the global dimension of bioethics was unclear because the meaning of the term "global" was unsuitably explained, which led to erroneous interpretations. For the sake of the clarity of this study and in order to avoid ambiguities, the meaning of "global bioethics" will be further on explained.

\section{Bioethics - from local to global}

Along the years, a few meanings of the term "global bioethics" (as used by specialists) have been highlighted. For some, it is a call for globalizing the study of bioethics from a perspective focusing on the third world zones. For others, global bioethics encompasses one sole set of global principles. Additionally, the third meaning of global bioethics refers to the research field of bioethics on a global level. ${ }^{2}$ This study will approach global bioethics from the perspective of the existence of a set of universal principles present in local bioethical contexts.

Globally, there are common ethical principles recognized as values within different local cultural traditions. Practically, we are discussing local-level principles, extant within communities, which

\footnotetext{
${ }^{1}$ V. R. Potter, Bioethics: Bridges to the Future (New Jersey: Prentice Hall, 1971), 1.

${ }^{2}$ Søren Holm and Bryn Williams-Jones, "Global bioethics - myth or reality?," BMC Medical Ethics 7 (2006).
} 
incorporate both specific elements (with a personal note), as well as universal principles. A different level is represented by the principles which transgress the local and form a universal set generally applied in global bioethical practices. Although we make reference to the two levels of action and interpretation (the local and the global), it is our opinion that they do not reflect a relationship of subordination, but one of interaction. Therefore, universal principles are neither delivered nor imposed by an external authority without a connection to the local dimension of ethical traditions, but they strive and are revealed to have universal aspirations on a local level.

T. L. Beauchamp and J. F. Childress identified a set of ethical principles derived from the collective cross-cultural morality, present in most ethical traditions - based on these principles, they set up the system of principlism, a procedure of evaluation and moral decision-making, which is an instrument for reflection and a guide for analysis which serves the needs of bioethics. The fundamental theory of T. L. Beauchamp and J. F. Childress is also known as "the Four Principles" or the "Georgetown Mantra." These principles are: respect for autonomy, justice, beneficence, and non maleficence. ${ }^{3}$ The two authors argue that "all persons, in all cultures who are serious about moral conduct, do accept the demand of the common morality". ${ }^{4}$ The cross-cultural character and the independence from all the traditional ethical theories were considered elements which could contribute to the global dimension of bioethics, as they can be applied in specific bioethical contexts. At the same time, these principles are present in most cultures and are not imposed as exterior elements, but are incorporated as local values.

Consequently, the local is interconnected with the global - where it is revealed through the principles it delivers. This way, a crossover is made from the local dimension to a global one, possible through the very universal principles given by the traditions of local ethics. The problems under debate are more and more complex, not only on a theoretical level, but especially in the practical applications, on particular cases. However, the global dimension of bioethics does not include a unique normative frame, a sole set of norms.

- Global bioethics - how not to define it

Global bioethics cannot be interpreted as an attempt which (on a theoretical level and in its practical application) implies the usage of a sole normative frame, with the same set of moral norms and principles. Bioethicians use different frames for ethical evaluation, based on ethical theories, on principles and methods which are sources for this enterprise - there exist however also local cultural influences which have been mentioned above and which must be taken into consideration. Different cultures have different values and moral codes which guide them, beyond the extant universal principles. A unified frame of global bioethics should not lead to the idea that all bioethicians should act in the same way anywhere in the world. A global bioethical frame implies the collaboration between specialists in different fields (philosophy, sociology, medicine, theology, psychology, etc.) who are interested in the same subjects and work with similar information sources. In their actions, they also consider the local element. Furthermore, global bioethics should not be confused with an attempt to an approach to a unitary religion.

The global establishment of specialized bioethics within religions or cults (such as Confucian bioethics, Buddhist bioethics, Christian bioethics, etc.) can offer important elements for a set of

\footnotetext{
${ }^{3}$ Tuja Takala discusses the "the four principles approach" and the limit of their application in his paper titled "What is Wrong with Global Bioethics? On the Limitations of the Four Principles Approach", in Cambridge Quarterly of Healthcare Ethics 10 (2001): 72-77.

${ }^{4}$ T. L. Beauchamp and J. F. Childress, Principles of Biomedical Ethics (New York: Oxford University Press, 2001), 4-5.
} 
principles which could be used globally - but this is the sole purpose they can be used for. The differences between the major religions, especially on a dogmatic level, do not facilitate a global enterprise. There is however a global religious collective moral background which also encompasses values which can be used in a global bioethics dialogue. From this point of view, we believe that the world religions can bring major contributions to the construction of global bioethics through the values they can offer. However, global bioethics is not "international" bioethics, although it implies normative principles or ethical guidelines which spring from the local environment and may be well applied in a global context.

- Why is bioethics becoming global?

The demarcation of global bioethics and the usage of the term itself in the past decades are in strong connection with the process of globalisation and all its implications - especially concerning the circulation of people and information worldwide, as well as the spread of biotechnologies used in human sciences. The process of migration is also concerned with the movement of researchers in education, health, ecology, etc. from their country of origin to more developed countries. Based on the information from OECD $2010^{5}$ in New Zeeland, Ireland, and the United Kingdom, over $30 \%$ of their doctors are educated elsewhere.

The process of decision-making in bioethics was changed by globalization, as reference points and principles with global coverage were formulated by institutions such as UNESCO. The Universal Declaration on Bioethics and Human Rights ${ }^{6}$ is addressed to states, but it also offers decisional and practical guidance for various groups, communities, individuals, and public and private institutions. It may be argued that the document represents a global consensus through the 15 general principles it covers. The usage and interpretation of each principle is however determined by the specific elements of the social, cultural, and religious context in which it operates.

Without a doubt, bioethics promotes global cooperation in scientific research and supports projects which deal with health and the well-being of people and nature. Furthermore, bioethics is a means of communication between scientists and the civil society, a platform for interdisciplinary dialogue especially as bioethics implies specialists from a wide array of fields such as philosophy, biology, medicine, physiology, etc. Student and research exchanges within international programmes stimulate research, the transfer of ideas, knowledge, and technology. The information delivered by the European Commission $(2012)^{7}$ shows that the programme for exchange students which began in 1987 with 3.244 students reached a participation rate of over 230.000 students in the 2010/2011 academic year.

A new phenomenon which makes bioethics global is medical tourism. Normally, patients either treat their health problems in their countries of origin or, if they reside in less developed countries, they opt for treatment in more developed countries where they feel more suitable, complex, and efficient treatments can be provided. However, there are also situations in which patients from developed countries travel to less developed countries which seem more attractive from the

\footnotetext{
5 The Organisation for Economic Co-operation and Development. International migration of health workers. Policy Brief. (2010), http:// www.oecd.org/migration/mig/44783473.pdf (last time accessed: March 3, 2016).

${ }^{6}$ The Universal Declaration on Bioethics and Human Rights was adopted at the UNESCO General Conference from October 19. It offers a general frame of principles and procedures which can guide states in the process of creating laws, policies, or other instruments used in bioethics. See: http://portal.unesco.org/en/ev.phpURL_ID=31058\&URL_DO=DO_TOPIC\&URL_SECTION=201.html, (last time accessed: March 3, 2016).

7 The European Commission, 2012. Lifelong learning programme. The Erasmus Programme 2010-2011. A statistical overview. http://ec.europa.eu/education/erasmus/doc/stat/1011/report.pdf. (last time accessed: March 3, 2016).
} 
perspective of treatment - this may happen because of certain local ethical interpretations which impose restraints on certain types of practices.

Global bioethics, from the perspective of practice and reflection, is accompanied by a global bioethical education which promotes moral values, principles, and ethical decision frames aiming to develop a moral conduct. Bert Gordjin argued that in order to have a moral conduct, knowledge is an essential condition, just like the development of a moral character. ${ }^{8}$ Bioethical education is strongly connected to contemporary global bioethical problems: organ trade, climatic changes, bio-terrorism, the degradation of the biosphere, malnutrition and pandemics, etc. ${ }^{9}$ Ethical problems are interconnected and need transnational solutions, thus solving problems on a state level of ethical norms is not sufficient anymore. We meet the same situation in bioethical education. There is a tendency of moving the effort of bioethical education from its local dimension to collective transnational activities with the purpose of information exchange and the harmonization of content and methodologies. In this sense, the first step is determining a global platform for ethical education which facilitates the exchange of educational experiences, as well as the contact with other similar specialists and intuitions worldwide.

\section{Arguments for global bioethics}

\section{A. Human rights}

The Second World War, with all its atrocities, its practices of human sterilization, involuntary active euthanasia, and brutal experiments on human subjects, generated international actions for the protection of human life and dignity. The preoccupation of governments with human rights and fundamental liberties was materialized in documents signed and approved internationally. The Universal Declaration of Human Rights, adopted in 1948, was followed by other conventions and agreements which supplemented the rights a person must have, aiming racial discrimination, poverty, corruption, and lack of equal access to health services. The documents referring to medical ethics (The Declaration of Geneva, The Nurenberg Declaration of Human Experimantation and The International Code of Medical Ethics) brought new elements whose major objective was the protection of human life and dignity. Human rights, as understood internationally and institutionally, are based on a set of human interests recognized by most people as essential conditions for a life lived in dignity. Every person should benefit and be supported by these rights, regardless of the territory where they live. The period when these documents were adopted approximately corresponds to the time when bioethics benefited from an exceptional development.

In the past decades, bioethics developed in such a way that it started to try to answer the new global challenges (pandemics, human genetic engineering, population control, etc.). Consequently, global bioethics claimed an extension of human rights, especially on an institutional level. Arguing that the traditional principles of bioethics are too much concentrated on the individual (who is not globallyoriented), some specialists supported the idea that human rights could give a good guidance in difficult situations which affect entire populations and nations. ${ }^{10}$

In some authors' opinion, the closeness between bioethics and human rights are rooted in the Antiquity. Therefore, according to Davey, medical ethics (the ancestor of bioethics) and its

\footnotetext{
8 Bert Gordjin, "Moral Improvement Through Ethics Education," in Bioethics Education in a Global Perspective: Challenges in global bioethics, ed. Henk A.M.J. ten Have (Dordrecht: Springer, 2015), 177-195.

${ }^{9}$ Henk A.M.J. ten Have, "Global bioethics: Transnational experiences and impacts on Islamic Bioethics," Zygon: Journal of Religion and Science 48 (3) (2013): 600-617.

${ }^{10}$ John D. Arras and Elisabeth M. Fenton, "Bioethics and Human Rights: Access to Health-Related Goods," Hastings Center Report 39 (5) (2009): 27-38.
} 
fundamental principles may be regarded as derived from the Hippocratic tradition. ${ }^{11}$ A number of articles from the Universal Declaration of Human Rights are juxtaposed with the specific norms of bioethics: the respect for human dignity and equality (articles 1 and 2) and the right to life (article 3). However, some articles of international documents dealing with bioethics also include elements of human rights, such as:

a) The UNESCO Universal Declaration on the Human Genome and Human Rights (1998), in which the human genome is declared to be part of the human collective patrimony, thus any practices which violate human dignity are forbidden.

b) The UNESCO Universal Declaration on Bioethics and Human Rights (2003), which promotes bioethics in a normative global dimension

The superposition of some norms from the two fields is also highlighted by the fact that more legal courts, on a regional and national level, interprets bioethical norms (at least partially) in terms of international human rights. T. Fauce mentions three such instances: The English Court of Appeal and The House of Lords, as well as The European Court of Human Rights. One example in this sense is the case of $D$., a patient infected in his country of origin with HIV and expelled from the United Kingdom. Following a request made by $D$., the European Court of Human Rights decided that his expulsion was an act which violated his right to be protected from degrading situations. His expulsion would have led to an inadequate medical treatment. ${ }^{12}$ Specialized literature shows legal cases on bioethical practices which are influenced by the international norms of human rights, often times in order to correct certain legal gaps of ambiguities.

Internationally-acknowledged human rights promote principles which cannot be negotiated and which bring a normative force to the bioethical discourse. ${ }^{13}$ Using human rights to support bioethics is based on both their tendencies towards universality and their common purpose - aiding the human being. The human well-being and the quality of life have a universal character and are not determined by ethnicity, sex, or geographical setting. The internationalization of fundamental human rights and the consistent juxtaposition of human rights with basic bioethical and environmental precepts facilitate the globalization of bioethics.

\section{B. Cultural pluralism and bioethics}

Bioethical principles and (especially) bioethical practices can be influenced by cultural environments. Culture is a concept difficult to define, hence its numerous definitions. T. Bracanovic considers that the problem of the numerous definitions given to "culture" is based on the fact that they are all too inclusive. ${ }^{14}$ Without trying to clarify the debate, we highlight that UNESCO, in its Universal Declaration of Cultural Diversity ${ }^{15}$ gave the following definition to culture: "the set of distinctive spiritual, material, intellectual and emotional features of society or a social group, and that it encompasses, in addition to art and literature, lifestyles, ways of living together, value systems, traditions and beliefs."

As stressed above, global bioethics does not imply the standardization of practices. The four principles of the "Georgetown Mantra" are part of a unitary set, but their usage is different in various cultural contexts because of traditional backgrounds and different understandings of the essence of the principles. For instance, the understanding of the concept of "goodness" may have a negative connotation in a different culture and thus the principle of beneficence may receive ambiguous meanings. As principles, they may be generalized, but their usage may differ. A delicate subject in

\footnotetext{
${ }^{11}$ L. M. Davey, “The Oath of Hippocrates: An historical review," Neurosurgery 49 (2001): 554-566.

12 Thomas Faunce, "Bioethics and Human Rights," in Handbook of Global Bioethics, ed. Henk A.M.J. ten Have, Bert Gordjin (Dordrecht: Springer, 2014), 467-484.

${ }^{13}$ Henk Ten Have, Global Bioethics: An introduction (New York: Routledge, 2016).

14 Tomislav Bracanovic, "Respect for cultural diversity in bioethics. Empirical, conceptual and normative constraints," Med Health Care and Philos 14 (2011): 229-236.

15 UNESCO The Universal Declaration on Cultural Diversity (2001). http://portal.unesco.org/en/ev.php$\underline{\text { URL_ID }=13179 \& U R L \_D O=D O}$ TOPIC\&URL_SECTION=201.html (last time accessed: March 3, 2016).
} 
more than one culture is represented by both euthanasia and the problem of access to medicallyassisted reproduction, because cultural diversity created different practices. Every society has a set of moral norms which govern the individual action of its members, as well as of the community as a whole. Transmitted from generation to generation, these principles and practices form a culture. The community understands these norms as valuable and they relate to it. Practically, they are the ethical fundament of a community.

The four principles (respect for autonomy, justice, beneficence, and non maleficence), based on collective morality, represent the globalization process of bioethics which transcends cultural differences. The authors of principlism did not set an order for the four principles, but applied the prima facie rule, thus any one of them can be placed on the first position. However, autonomy may be placed after beneficence and justice, depending on the case. This flexibility, as an internal dynamics of the method, facilitates the applicability in cultural context. In order to exemplify the different approaches in various cultural models, we will highlight the problematic of access to medicallyassisted human reproduction techniques. This issue is more visible on a normative level as some states are more restrictive, while others have a more liberal legislation. A telling example is that of the comparison between Spain and Sweden. The Swedish society is often perceived as more morally liberal, when compared to the Spanish Catholic zone. As a consequence, one would expect that the Swedish legislation be more permissive. However, it presents itself differently: the Swedish law is restrictive while the Spanish one is much more liberal. The explanation stands in the consistency of moral tradition and social dynamics. Therefore, in Sweden, the law has accentuated the responsibility of procreation by conditioning access to technologies on criteria such as age or the existence of a partner; in Spain however, the access to technology was a reaction to the desire of liberation from Franco's regime, the decision being exclusively the choice of the woman. ${ }^{16}$

This example does not lead to the idea of the impossibility of global bioethics, but it highlights the influence of the socio-cultural context and the respect for cultural diversity within this process of globalization. Global cultural entities and bioethics should not be regarded as static realities. Every entity has an internal dynamism and the usage of bioethical principles, of universal human rights is not done in an absolute manner. The cultural specificity is an element which is considered without disadvantaging the global dimension of bioethics. This means that the hierarchy between different cultural values would be eliminated and cultural systems which can generate their own social norms would be recognized. Therefore, bioethics is a social and cultural construct which supports rights, values and beliefs to which researchers relate all the more as time passes.

\section{The role of religion and its influence in bioethics}

Contemporary bioethical approaches are much oriented towards philosophy, anthropology, and medicine. However, religion does play an important role in bioethics, concerning individual evaluations and decisions, as well as debates in the public space. For many people, religious traditions are important resources for moral deliberation and just as important reference points when it comes to organizing life and decisions. We believe that the religions of the world (Christianity, Judaism, Islam, Buddhism, Confucianism, etc.) play an important role in bioethics because, one the one side, religious beliefs are probably the strongest human beliefs, while on the other side, religious norms can contribute to our understanding of morality. Furthermore, because the subject of human bioethics is the human being along its existence (from birth until death), we believe that bioethics cannot discuss real issues unless the religious dimension is also considered. It is thus important that bioethicians have a clear understanding of the religious models and traditions, and its essential concepts: birth, life, health, sickness, suffering, death.

The fact that mainly ethical theories were used in bioethics created a type of dissatisfaction among philosophers regarding the universal character of these theories and regarding the procedure of moral decision-making which may lead to a lack of consensus - it was within this context that an anti-theory

\footnotetext{
${ }^{16}$ Stefano Rodota, "Cultural Models and Future in Bioethics," Journal of Contemporary Health Law and Policy 10 (1994): 33-45.
} 
was developed. ${ }^{17}$ A. Maclean suggested that a new strategy for bioethical debates was needed. Of course, the role of ethical theories in bioethics is important, and accepting the pluralism of ethical evaluations should be interpreted as a possibility for detailed evaluation, from various perspectives, which offer the chance to eliminate possible sources for errors. ${ }^{18}$ Therefore, we believe that approaching bioethics solely from the perspective of principles and laic ethical norms is however incomplete and erroneous for the purpose of the holistic understanding of problems - in case, of course, the religious dimension is not present. Religious traditions give people their most important symbolic resources, so that considering religion within bioethics is inevitable.

However, the question which must be asked is the following: what contributions could the great religions of the world and theology in general bring into the field of bioethics? Theological concepts and religious beliefs can generate normative principles helpful to decision-making in bioethics, while they can also be sources on which cultures can mould. Also, theology can offer arguments for people who use philosophical fundaments for their theories. Furthermore, theology can bring to bioethics a specific methodology of argumentation based on sacred texts. ${ }^{19}$

Important concerns for bioethics are represented by the new technologies for medically-assisted human reproduction and the usage of embryo stem cells - this issue being in direct connection to the principle of respect for the human life. While this principle is clearly understood institutionally and in all international documents related to this issue, it is however unclear, from a religious point of view, which is the exact moment in which human life begins. From this point of view, debates have been extended over the issue of abortion.

People belonging to different cultures and religions may have radically different perspectives on human conception, the beginning of human life, the status of the embryo, and the permission of abortion. For instance, for Hindus and Buddhists, a human being exists even before his/her conception. ${ }^{20}$ Hebrew tradition considers that the embryo is a not a being until it is 40 days old, which explains the decision of Israeli officials in 2001 to allow outnumbered embryos to be used for research purposes, if the donors agree. According to the Talmud, human life begins with the birth, thus when the child's head (born on time) becomes visible, it receives an equal status to that of its mother. Rabbinic literature then extended the acquirement of human status to only 13 days after birth, arguing that the viability of the child can only be defined after this period had passed. For Muslims, the beginning of individual human life is tied to the act of embryo animation, an event which took place some 120 days after conception. Christian bioethics is based on the Gospels and on the writings of the Holy Fathers. The beginning of human life is also connected to the moment of the act of embryo animation, the embryo being considered a human being: "The human being is regarded and treated as a person from the moment of its conception; at the same time, its rights as human being must be recognized, the first of which being its inviolable right to life."21

It is therefore visible that there is no consensus between the bioethics of the great religions regarding the issue of the beginning of human life and the status of the embryo. This type of consensus is also missing from other subjects approached by religious bioethics, which may lead to the idea that the status, the role, and the influence of religion in bioethics is minimal, if not even controversial. The bioethical consensus of religions cannot be accomplished as religions are based on different authoritative sources and are influenced by different local cultural traditions. Under these circumstances, one may ask whether certain common elements can be identified within religions, so

\footnotetext{
17 See: Anne Maclean, The Elimination of Morality. Reflections on Utilitarism and Bioethics (London: Routledge, 1993); R.B. Louden, Morality and Moral Theory. A Reappraisal and Reaffirmation (Oxford: Oxford Unoversity Press, 1992).

${ }^{18}$ Maria Sinaci, Normativitate şi bioetică. Aspecte filosofice contemporane [Norms and bioethics. Astepcts of contemporary philosophy] (Cluj-Napoca: Presa Universitară Clujeană, 2014), 135-136.

${ }^{19}$ Janine Marie Idziak, "Theology and Discipline of Bioethics," Bioethics Forum (1992) 8 (3): 13-17.

${ }^{20}$ P. Singer and A.M. Viens (eds.), The Cambridge textbook of bioethics (Cambridge: Cambridge University Press, 2008), 379-441.

${ }^{21}$ Congregaţia pentru Doctrina Credinţei [The Congregation for the Doctrine of Belief], Donum vitae 46 (Iaşi: Presa Bună, 2001).
} 
that a dialogue could be born between religious traditions and between religious and lay people. Can religious beliefs and religious systems represent a basis for global bioethics?

The interest of world religions in global ethics was visible in the Parliament of the World's Religions meeting in Chicago in 1993 when the Declaration Toward of Global Ethics ${ }^{22}$ was proclaimed. This declaration confirmed that "here is already a consensus among the religions which can be the basis for a global ethic - a minimal fundamental consensus concerning binding values, irrevocable standards, and fundamental moral attitudes." 23 It should be stressed that this document should not be interpreted as an attempt to synthesize the great religions, or to create a global religion which transcends all religions or which substitutes them. The declaration highlights a few ethical values which are common to all religions and which can be (or which are) adopted by believers, nonbelieves, researchers, philosophers, bioethicians, and theologians. The purpose is to stress those elements which bring together the great religions, not those which separate them. Theological disputes are especially visible in the area of dogmatic theology. ${ }^{24}$

The Golden Rule is tightly related to Christian ethics, but it is a principle with a wide history, thus present in Hinduism, Buddhism, Taoism, and the other religions of the world. The most well-known reference to the Golden Rule (at least in the Western world) is derived from the Sermon on the Mount, when Jesus Christ advised people to do no harm, but to do good to their peers, treating all of them equally: "So in everything, do to others what you would have them do to you, for this sums up the Law and the Prophets" (Matthew 7:12). In the contemporary world and without using any religious terms, the Golden Rule could be translated as following: "Treat people as you wish to be treated yourself!"

The first tendency is to interpret the Golden Rule as it is literally formulated, thus as a principle of reciprocity - treat your peer as you wish (s)he treated you. In fact, closely analyzing, one discovers that the Golden Rule contains and also generates others principles. If person X treats $\mathrm{Y}$ as X expects it, then $\mathrm{X}$ recognizes $\mathrm{Y}$ as an equal regarding value and importance. Thus the Golden Rule supports the principle of equality and respect towards others. One principle which is at the basis of the Rule is autonomy, because $\mathrm{X}$ fully autonomously chooses to act in a certain way (positively) towards $\mathrm{Y}$. The Golden Rule also incorporates the principle of beneficence, as any human being desires to be treated well. Therefore, people indirectly receive the obligation to do good. If the principle of beneficence is distributed equally, then it is marked by justice. Furthermore, it is observable that the negative formulation of the Golden Rule ("do not do to others what you do not want them to do to you") also contains the principle of non maleficence, as no person desires to harm anybody.

Therefore, it is easily noticeable that the Golden Rule is connected to the four principles which form the "Georgetown Mantra" - respect for autonomy, justice, beneficence, and non maleficence - as promoted by J. Childress şi T. Beauchamp. It is our opinion that the Golden Rule may be regarded as a cross-cultural principle, a contribution of the religions to the globalization of bioethics. It promotes equality, respect, non-violence, and is largely applicable. This text especially referred to the Golden Rule as we consider that it plays a significant role in the process of global bioethics because it has a universal and highly-acceptable character.

\section{Conclusions}

This text argued that while global bioethics is possible in a globalized world, it is crucial to explain the significance of the term "global bioethics" in order to avoid misinterpretations and improper expectations. Global bioethics is neither international bioethics, nor a universal religion or an evaluation frame based on a set of norms applicable anywhere, to anyone, and anytime. The global

\footnotetext{
${ }^{22}$ The Declaration Toward a Global Ethics, http://www.parliamentofreligions.org/sites/default/files/TowardsAGlobalEthic.pdf (last time accessed: March 3, 2016).

23 Ibidem, 3.

${ }^{24}$ Maria Sinaci, "Global Ethics and Religious Value," in Debates on Globalization. Approaching National Identity through Intercultural Dialogue, ed. Iulian Boldea (Tîrgu Mureş: Arhipelag XXI, 2015), 300-309.
} 
bioethical construction is based on principles and ethical values recognized globally - princiles which guide this field of study, but whose interpretation and usage must be done considering local specificities. Only by this type of understanding can bioethics become global. This study argued the possibility of global ethics from the perspective of human rights, cultural pluralism, and the religions of the world (with particular stress on the Golden Rule). There are certain principles which successfully incorporate all these three fields and this fact supports the possibility of the existence of global bioethics, as defined at the beginning of this paper.

\section{References:}

Arras, D. John and Fenton, M. Elisabeth. "Bioethics and Human Rights: Access to Health-Related Goods." Hastings Center Report 39 (5) (2009): 27-38.

Beauchamp, T. L. and Childress, J. F. Principles of Biomedical Ethics. New York: Oxford University Press, 2001.

Bracanovic, Tomislav. "Respect for cultural diversity in bioethics. Empirical, conceptual and normative constraints." Med Health Care and Philos 14 (2011): 229-236.

Congregaţia pentru Doctrina Credinţei. Donum vitae 46 (Iaşi: Presa Bună, 2001).

Davey, L. M. "The Oath of Hippocrates: An historical review." Neurosurgery 49 (2001): 554-566.

Faunce, Thomas. "Bioethics and Human Rights". In Handbook of Global Bioethics, ed. Henk A.M.J. ten Have, Gordjin, Bert, 467-484. Dordrecht: Springer, 2014.

Gordjin, Bert. "Moral Improvement through Ethics Education.". In Bioethics Education in a Global Perspective: Challenges in global bioethics, ed. Have ten Henk A.M.J., 177-195. Dordrecht: Springer, 2015.

Have ten Henk. Global Bioethics: An introduction. New York: Routledge, 2016.

Have ten Henk A.M.J., "Global bioethics: Transnational experiences and impacts on Islamic Bioethics." Zygon: Journal of Religion and Science 48 (3) (2013): 600-617.

Holm, Søren and Williams-Jones Bryn. "Global bioethics - myth or reality?" BMC Medical Ethics 7 (2006).

Idziak, J.M. “Theology and Discipline of Bioethics.” Bioethics Forum 8 (3) (1992): 13-17.

Louden, R.B. Morality and Moral Theory. A Reappraisal and Reaffirmation. Oxford: Oxford Unoversity Press, 1992.

Maclean, Anne. The Elimination of Morality. Reflections on Utilitarism and Bioethics. London: Routledge, 1993.

Potter, V. R. Bioethics: Bridges to the Future. New Jersey: Prentice Hall, 1971.

Rodota, Stefano. "Cultural Models and Future in Bioethics." Journal of Contemporary Health Law and Policy 10 (1994): 33-45.

Sinaci, Maria. "Global Ethics and Religious Value". In Debates on Globalization. Approaching National Identity through Intercultural Dialogue, ed. Iulian Boldea, 300-309. Tîrgu Mureş: Arhipelag XXI, 2015.

. Normativitate şi bioetică. Aspecte filosofice contemporane [Norms and bioethics. Aspects on contemporary philosophy]. Cluj-Napoca: Presa Universitară Clujeană, 2014.

Singer P. and Viens A.M. (eds.). The Cambridge textbook of bioethics. Cambridge: Cambridge University Press, 2008.

Takala, Tuja. "What is Wrong with Global Bioethics? On the Limitations of the Four Principlies Approach." Cambridge Quarterly of Healthcare Ethics 10 (2001): 72-77.

\section{Electronic sources:}

The Declaration Toward a Global Ethics, http://www.parliamentofreligions.org/sites/default/files/TowardsAGlobalEthic.pdf (last time accessed: March 10, 2016). 
The European Commission, 2012. Lifelong learning programme. The Erasmus Programme 20102011. A statistical overview. http://ec.europa.eu/education/erasmus/doc/stat/1011/report.pdf. (last time accessed: March 10, 2016).

The Organisation for Economic Co-operation and Development (2010). International migration of health workers. Policy Brief. www.oecd.org/migration/mig/44783473.pdf (last time accessed: March 10, 2016).

UNESCO The Universal Declaration on Cultural Diversity (2001). http://portal.unesco.org/en/ev.php-

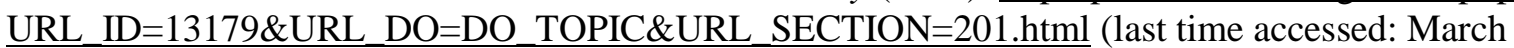
10, 2016).

The Universal Declaration on Bioethics and Human Rights, adopted at the UNESCO General Conference (October 19, 2005), http://portal.unesco.org/en/ev.php$\underline{\text { URL_ID }=31058 \& U R L \_D O=D O \_T O P I C \& U R L \_S E C T I O N=201 . h t m l}$, (last time accessed: March $10,2016)$. 